\title{
DYSTRYBUCJA PRODUKTÓW DLA ROLNICTWA W POLSCE - W POSZUKIWANIU NOWYCH ŹRÓDEŁ PRZEWAGI KONKURENCYJNEJ
}

\author{
Zenon Pokojski \\ Laboratorium Praktyki Biznesu, Uniwersytet Marii Curie Skłodowskiej w Lublinie \\ Kierownik Katedry: dr hab. Jan Chadam
}

\begin{abstract}
Słowa kluczowe: kanał dystrybucji, dystrybutor, rolniczy łańcuch wartości Key words: distribution channel, distributor, agricultural value chain

S y n o p s i s. Do 2004 r. dystrybucję produktów dla rolnictwa w Polsce uważano za stosunkowo słabo rozwiniętą na tle innych krajów Europy. Wskazywano dużą liczbę małych przedsiębiorstw prowadzących dystrybucję, których strategie opierały się głównie na konkurencji cenowej. Jednak ta sytuacja po przystąpieniu Polski do Unii Europejskiej zaczęła się szybko zmieniać. Liczba podmiotów zaczęła się zmniejszać, a dystrybutorzy zaczęli przejmować funkcje hurtowników oraz detalistów. Model biznesowy dystrybucji w Polsce wciąż ewoluuje, dostosowując się do dynamiki zmian oczekiwań klientów. Celem pracy jest zaprezentowanie zmian w dystrybucji jako ogniwa rolniczego łańcucha wartości. Na podstawie przeglądu literatury, danych z raportów SMGP i Ibris za lata 2014 i 2015 oraz obserwacji uczestniczącej autora jako wiceprezesa zarządu GA Puławy nadzorującego omawiany obszar przedstawiono nowe aspekty w działalności dystrybutorów takie jak usługi doradztwa rolnego i organizację finansowania działalności gospodarczej rolników.
\end{abstract}

\section{WSTĘP}

Rynek rolny uległ bardzo istotnym przeobrażeniom po przemianie ustrojowej w Polsce, których dynamika przybrała na sile po wstąpieniu do Unii Europejskiej (UE). Na polską wieś i do rolnictwa trafiła 1/3 transferów z budżetu UE. W latach 2004-2013 Polska otrzymała w ramach wsparcia wynikającego ze wspólnej polityki rolnej 29,4 mld euro [Nurzyńska, Poczta 2014]. Pojawiły się nowe podmioty w łańcuchu wartości produkcji rolnej, zwiększyła się dochodowość we wszystkich ogniwach tego łańcucha, diametralnie zmienił się model obsługi producentów rolnych. Ważne w procesie dystrybucji środków do produkcji rolnej do 1989 roku podmioty, takie jak np. Spółdzielnia Gminna „Samopomoc Chłopska” czy spółdzielnie kółek rolniczych, odgrywają obecnie znacznie mniejszą rolę. Rozwinęły się zaś firmy prywatne, które bardzo często działalność rozpoczynały na bazie majątku upadającej spółdzielczości wiejskiej. Celem opracowania jest określenie zmian w dystrybucji rozumianej jako ogniwo rolniczego łańcucha wartości. 


\section{DYSTRYBUCJA W ROLNICZYM ŁAŃCUCHU WARTOŚCI}

Model dystrybucji kształtował się w krajach o gospodarce wolnorynkowej przez dziesiątki lat. Najczęściej prezentowany jest jako ogniwo łańcucha wartości opracowanego przez Michaela E. Portera pod koniec lat 70. XX w. [Porter 2001, s. 50-66]. Koncepcja ta pokazuje, w jaki sposób dystrybuowane są korzyści, jak migruje wartość w poszczególnych ogniwach tego łańcucha (rys. 1.).

\begin{tabular}{|c|c|c|c|c|c|c|}
\hline $\begin{array}{c}\text { Zarządzanie } \\
\text { łańcuchem } \\
\text { zaopatrzenia }\end{array}$ & & Zarza & $\begin{array}{c}\text { Kanały } \\
\text { dystrybucji i } \\
\text { formy } \\
\text { sprzedaży }\end{array}$ & $\begin{array}{l}\text { Zarządzanie } \\
\text { relacjami z } \\
\text { klientami }\end{array}$ & & $\begin{array}{l}\text { Postrzegana } \\
\text { wartość: } \\
\text { produktu, } \\
\text { firmy }\end{array}$ \\
\hline $\begin{array}{c}\text { Dostawcy jako } \\
\text { partnerzy w } \\
\text { sieci produkcji }\end{array}$ & $\begin{array}{l}\text { Zdolność } \\
\text { do tworzenia } \\
\text { innowacji }\end{array}$ & $\begin{array}{c}\text { Zdolność do } \\
\text { wytwarzania „w } \\
\text { klasie światowej” } \\
\text { zapewniającego } \\
\text { wartość użytkowa } \\
\text { i indywidualizacje }\end{array}$ & $\begin{array}{l}\text { Kanały i formy } \\
\text { sprzedaży } \\
\text { zgodne z } \\
\text { preferencjami, } \\
\text { możliwościami } \\
\text { i zwyczajami } \\
\text { klientów }\end{array}$ & $\begin{array}{c}\text { Satysfakcja } \\
\text { i lojalność } \\
\text { klientów, stały } \\
\text { kontakt, zdolność } \\
\text { do odpowiedzi na } \\
\text { potrzeby }\end{array}$ & $\begin{array}{c}\text { Obsługa oparta } \\
\text { na znajomości } \\
\text { potrzeb, } \\
\text { oczekiwań, } \\
\text { wymagań, } \\
\text { marzeń }\end{array}$ & $\begin{array}{c}\text { Zdolność do } \\
\text { przyciągania } \\
\text { wartościowych } \\
\text { klientów, } \\
\text { inwestorów, } \\
\text { partnerów }\end{array}$ \\
\hline
\end{tabular}

Rysunek 1. Tworzenie wartości w łańcuchu wartości

Źródło: [Koźmiński 2004, s. 121].

W tym modelu biznesowym istotną rolę odgrywają dwie funkcje: tworzenie wartości i wychwytywanie wartości, czyli uzyskiwanie najwyższych marż w łańcuchu przez firmy, które uczestniczą w wytworzeniu produktu i dostarczeniu go odbiorcy [Koźmiński 2004]. Budowane strategie rozwoju firm polegają najczęściej na wydłużeniu własnego łańcucha wartości bądź poszerzeniu jego ogniw, tak by mieć większą siłę wpływu i przejmować jak największą wartość w całym łańcuchu. Bo, jak wskazał Andrzej Koźmiński najwyższe marże uzyskuja najsilniejsi w tym znaczeniu uczestnicy tańcucha - ci, którzy moga wybierać sobie partnerów spośród wielu konkurujących ze soba kandydatów, oraz ci, o których względy trzeba zabiegać cena i atrakcyjnościa oferty, czyli kosztem marży [Koźmiński 2004, s. 120]. Globalni liderzy dostrzegają w dystrybucji kluczowy czynnik sukcesu rynkowego, porządkują ogniwa łańcucha wartości szczególnie silnie integrując z własnym biznesem dystrybucję [Dawson 2014]. W ostatnim okresie coraz większą popularność zdobywa koncepcja globalnego łańcucha wartości, w skrócie GVC (ang. Global Value Chain) [Grochowska 2014]. Koncepcja ta uwzględnia poza produkcją cały zakres działań, od projektowania produktu przez marketing po dostawę klientowi finalnemu.

Szczególnie duże znaczenie ma dystrybucja jako ogniwo łańcucha wartości w okresie kryzysów ekonomicznych. Adekwatnym przykładem na rynku rolnym było zachowanie producentów nawozów, takich jak Agrium czy Koch Fertilizers. W latach 2006-2007, kiedy ceny gazu ziemnego w Stanach Zjednoczonych osiągnęły bardzo wysoki poziom i produkcja nawozów stała się nieopłacalna, wspomniane koncerny postanowiły szukać szans rozwoju w przejmowaniu aktywów dystrybucyjnych, czyli postanowiły przejąć kontrolę nad większą liczbą ogniw rolniczego łańcucha wartości. Podkreślano realizowanie strategii, mającej na celu obecność Grupy w każdym elemencie łańcucha wartości. Strategia ta została więc ukierunkowana na dobrze rozwinięty obszar dystrybucji. Agrium utworzyło ponad 1500 placówek detalicznych oraz rozbudowaną sieć dystrybucji hurtowej i nadal rozszerza działalność dystrybucyjną, m.in. przez akwizycję. Ponadto spółka ta zdecydowała o m.in. świadczeniu usług doradczych, które w ostatnich latach stały się istotnym źródłem dodatkowych dochodów firmy [Agrium 2010]. Podobne działania 
podjęła Yara. Niezależnie od prowadzonej integracji poziomej podejmowała również działania w obszarze integracji pionowej, wzdłuż łańcucha wartości, obejmujące procesy optymalizacji logistyki i dystrybucji. Celem tych działań było skrócenie kanału dystrybucji. Firma utworzyła joint venture z DLG i AgroDK w Danii, tzw. Ferti Suplay - podmiot, który przejął wszystkie funkcje logistyczne. Yara w publikowanych materiałach wskazuje na własny, unikalny model biznesowy pozwalający na uzyskanie wpływu na wszystkie ogniwa rolniczego łańcucha wartości (rys. 2.). Koncern dowodzi również, że dysponując wpływem na wszystkie ogniwa łańcucha oddziałuje również na obszary niebędące pod jego bezpośrednią kontrolą. Przykładem ma być współpraca z klientami, z którymi dzieli się zdobytą wiedzą rolną.

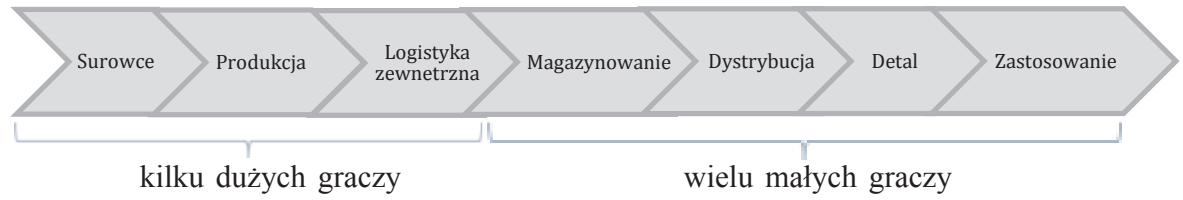

Rysunek 2. Łańcuch wartości Yary

Źródło: [Yara 2011, s. 6-7]

Inny europejski producent nawozów - Agrofert prowadzi dystrybucję głównie poprzez spółki zależne. Agrofert jest zintegrowanym przedsiębiorstwem, aktywnym zarówno w segmencie produkcji, jak i dystrybucji nawozów oraz innych produktów sektora chemicznego i rolniczego. Strategia tej firmy zakłada rozwój poprzez akwizycję i konsolidację rynku, również w obszarze dystrybucji. W 2017 r. grupa Agrofert skupiała ponad 250 spółek. Dostęp do odbiorców poprzez spółki zależne przyczynia się do stabilizacji cen i wyników finansowych firmy.

Sieć dystrybucji w każdym europejskim kraju spełnia kluczową rolę stabilizującą płynny przepływ wytwarzanych produktów. Należy bowiem pamiętać, że nawozy produkuje się cały rok, natomiast aplikuje przez 2-3 miesiące. Utrzymanie ciągłości produkcji ma istotny wpływ na efektywność ekonomiczną wytwarzania oraz bezpieczeństwo energetyczne i procesowe.

Kanały dystrybucji wykorzystywane w Europie różnią się w poszczególnych krajach długością i szerokością. Dłuższe i szersze występują w krajach Europy ŚrodkowoWschodniej i są niejako konsekwencją poprzedniej formacji społeczno-gospodarczej. Trzeba jednak zauważyć, że dystans tych różnic zmniejsza się. W krajach o długiej tradycji gospodarki wolnorynkowej dostawcy środków do produkcji rolnej oferują szeroki asortyment usług i produktów, w tym takie jak magazynowanie, transport, wynajem bądź leasing sprzętu rolniczego, a nawet zarządzanie ryzykiem przez instrumenty zabezpieczenia ceny [Berger 2015]. W Europie ukształtowały się trzy dominujące rodzaje obsługi rolników:

- dystrybucja prowadzona przez spółdzielnie (ang. cooperatives), których współwłaścicielami są rolnicy,

- dystrybucja prowadzona przez firmy prywatne,

- własne systemy dystrybucji rozwijane przez producentów środków do produkcji rolnej. W tym podziale można dostrzec próby zdominowania dystrybucji przez sąsiadujące ogniwa łańcucha: klientów ostatecznych - rolników oraz producentów środków dla rolnictwa. 


\section{DYSTRYBUCJA PRODUKTÓW DLA ROLNICTWA W POLSCE}

Dystrybucję produktów dla rolnictwa w Polsce powszechnie uważa się za stosunkowo słabo rozwiniętą na tle innych krajów Europy, takich jak Niemcy, Francja, Wielka Brytania, Holandia czy Belgia [Cioch, Kłosowska 2009, s. 28-30]. Po przystąpieniu Polski do Unii Europejskiej nastąpiły zmieny. Liczba podmiotów zmniejszyła się, dystrybutorzy częściowo przejęli funkcje hurtowników oraz detalistów. W wyniku przejęć zmniejszyła się liczba podmiotów w kanale daystrybucji. Szacuje się, że w Polsce w 2017 r. funkcjonowało około 200 podmiotów dystrybuujących środki do produkcji rolnej (rys. 3.). Najwięksi dystrybutorzy produktów dla rolnictwa w latach 2004-2017 zwiększyli kilkukrotnie przychody. Najważniejsi dystrybutorzy na rynku rolnym to firmy prywatne, w większości rodzinne, powstałe po 1989 roku. Do największych z nich należą: Chemirol, Osadkowski, Ampol-Merol i Agrolok. Warto zauważyć, że większość przedsiębiorstw dystrybucyjnych powstawała na bazie niewykorzystywanego majątku ówczesnych spółdzielni rolniczych czy państwowych gospodarstw rolnych.

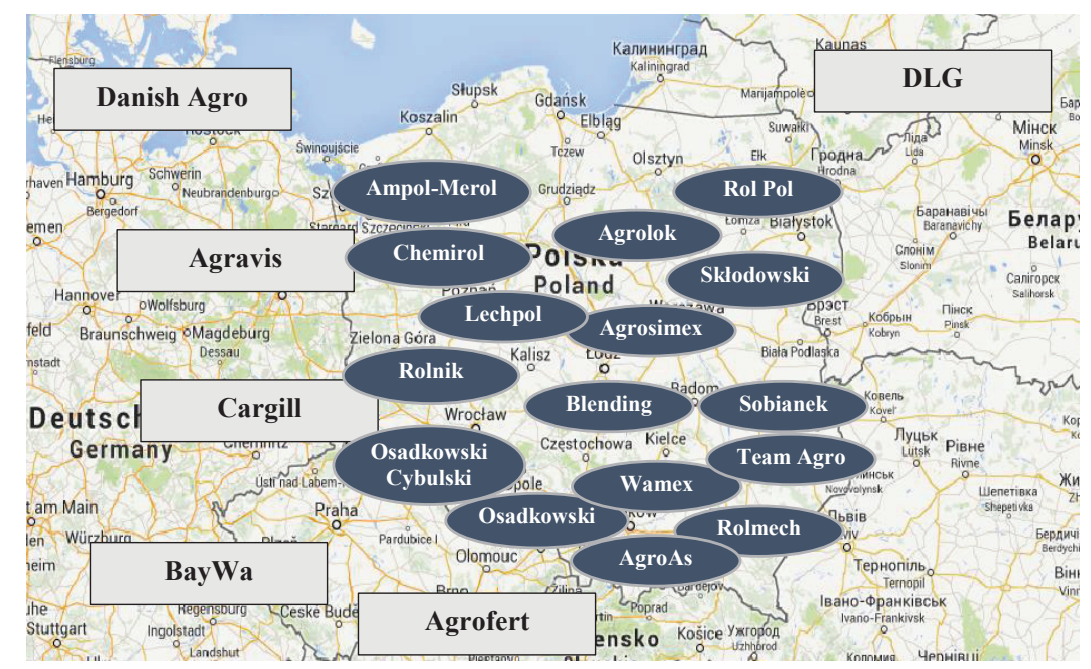

Rysunek 3. Wybrani dystrybutorzy środków do produkcji rolnej w Polsce Źródło: opracowanie własne.

Polska jest atrakcyjnym rynkiem rolnym, dlatego wejściem na ten rynek w zakresie dystrybucji interesują się koncerny zagraniczne, takie jak: Cargill, BayWa, DanishAgro, Agravis, DLG. Podmioty te mają obroty kilkukrotnie przewyższające obroty Grupy Azoty. Jednak także prywatne firmy dystrybuujące środki do produkcji rolnej w Polsce rozwijają się niezwykle dynamicznie. Co ciekawe, dynamika wzrostu jest nie tylko duża, ale i dość stabilna. Oznacza to, że dystrybutorzy potrafią umiejętnie wykorzystywać rezerwy rozwoju kształtującego się wciąż rynku rolnego (tab 1.). Dynamika wzrostu ich przychodów ze sprzedaży była wyższa od dynamiki największego polskiego producenta nawozów - Zakładów Azotowych Puławy. Firmy dystrybucyjne w ostatnich latach znacznie wzmocniły również wartość kapitałów własnych. Mimo że nie są one na tak wysokim poziomie jak w firmach dystrybucyjnych Europy Zachodniej, to dynamika wzrostu oscylująca wokół 10-20\% rocznie 
Tabela 1. Wartość przychodów ze sprzedaży największych dystrybutorów w Polsce w latach 2011-2016

\begin{tabular}{lcccc}
\hline Lata & \multicolumn{3}{c}{ Wartość przychodów ze sprzedaży [zł] } \\
\cline { 2 - 5 } & CHEMIROL & OSADKOWSKI & AGROLOK & $\begin{array}{c}\text { AMPOL- } \\
\text { MEROL }\end{array}$ \\
\hline 2011 & 1149295 & 1122538 & 966515 & 806107 \\
2012 & 1334878 & 1300720 & 1179925 & 1001934 \\
2013 & 1375183 & 1235783 & 1296930 & 1053485 \\
2014 & 1406538 & 1156217 & 1359909 & 1110840 \\
2015 & 1506794 & 1436996 & 1431630 & 1113782 \\
2016 & 1430398 & 1282546 & 1432311 & 1177418 \\
\hline
\end{tabular}

Źródło: opracowanie własne na podstawie rankingu Lista 500 dziennika „Rzeczpospolita” za poszczególne lata.

wskazuje, że wzmacnia się wartość składników majątkowych rodzimych dystrybutorów, choć ich wartość nadal na tle podobnych firm w Europie jest relatywnie niewielka.

Dystrybutorzy rozwój w dużym stopniu zawdzięczają poszerzaniu oferty dla przedsiębiorców rolnych. Coraz częściej oferują szkolenia, np. agronomiczne, a dla stałych klientów możliwość wymiany barterowej za dostarczone płody rolne. Wszyscy znaczący dystrybutorzy do rozwijania współpracy z rolnikami zatrudniają konsultantów rolnych oraz dbają o zacieśnianie relacji z klientami. Dostawa towaru do większego odbiorcy rolnego stała się już standardem.

Największy polski dystrybutor - Przedsiębiorstwo Handlowo-Usługowe Chemirol, powstałe w 1990 r., w 2017 r. zatrudniało prawie 900 osób, w tym ponad 250 pracowało w terenie nad rozwijaniem bezpośrednich relacji z rolnikami. Przedstawiciele przedsiębiorstwa są dodatkowo wspierani wiedzą zatrudnionych doradców rolnych - agrotechników. Z przeprowadzonych badań wynika, że w analizowanych firmach dystrybucyjnych (Chemirol, Osadkowski, Agrolok, Ampol-Merol) ponad 20\% pracowników stanowili przedstawiciele rolni, czyli pracownicy pracujący bezpośrednio z klientami. Na rysunku 4. przedstawiono województwa - obszar aktywności poszczególnych dystrybutorów.

Dystrybutorzy rolni w Polsce również poszukują możliwości wydłużenia łańcucha wartości, starając się przejąć mniejszych producentów nawozów czy środków ochrony roślin. Przykładem mogą być próby przejęcia Gdańskich Zakładów Nawozów Fosforowych czy Organiki Sarzyny z Grupy Ciech.

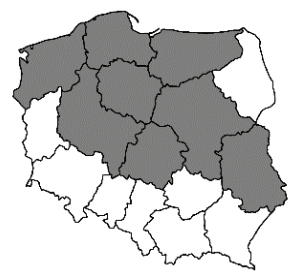

CHEMIROL

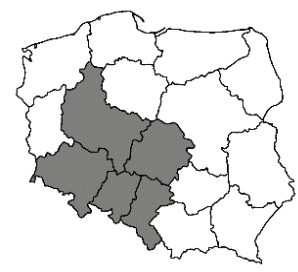

OSADKOWSKI

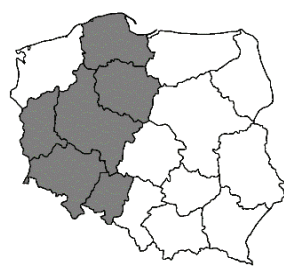

AGROLOK

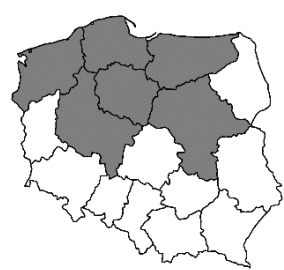

AMPOL-MEROL

Rysunek 4. Główne obszary działalności największych dystrybutorów w Polsce Źródło: opracowanie własne. 
Producenci środków do produkcji rolnej również zaczęli poszukiwać możliwości rozwoju przez:

- integrację poziomą (zwiększenie udziału w rolniczym łańcuchu wartości),

- integrację pionową (rozwój własnych kanałów dystrybucji),

- różne formuły partnerstwa $\mathrm{z}$ dystrybutorami.

Wybór strategii zależy w dużym stopniu od siły przetargowej producenta ${ }^{1}$. Grupa Azoty, przejmując Grupę Fosfory, nabyła również aktywa dwóch spółek dystrybucyjnych: Agrochem w Człuchowie i Dobrym Mieście. Grupa współpracuje z dystrybutorami w Polsce na podstawie rocznych kontraktów, udzielając wybranym partnerom autoryzacji.

Zmiany w dystrybucji środków do produkcji rolnej w Polsce przebiegały inaczej niż w innych krajach Europy Środkowo-Wschodniej. Podstawowym powodem była inna struktura gospodarstw rolnych - głównych klientów tego rynku, ich status prawny, ekonomiczny i społeczny. W Czechach, na Słowacji czy w Bułgarii nie było tak wielu małych, prywatnych przedsiębiorców rolnych.

\section{PRZEDSIĘBIORCY ROLNI JAKO KLIENCI DYSTRYBUCJI}

Model dystrybucji środków do produkcji rolnej determinują z jednej strony zachowania producentów, a z drugiej - oczekiwania i potrzeby przedsiębiorców rolnych. W Polsce w $2016 \mathrm{r}$. zarejestrowanych było 1407,7 tys. gospodarstw rolnych, w tym 1059,5 tys. gospodarstw do 10 ha użytków rolnych, 315,2 tys. gospodarstw od 10 do 50 ha oraz 33,0 tys. powyżej 50 ha. W rzeczywistości aktywnych gospodarstw rolnych jest mniej, ze względu na tzw. ciche dzierżawy $^{2}$. Polskie rolnictwo jest zatem stosunkowo rozdrobnione [GUS 2016 s. 107-109].

Pogłębiające się zróżnicowanie regionalne rozwoju gospodarstw rolnych ma uwarunkowania historyczne, środowiskowe oraz jest efektem odmiennych mechanizmów, które wyznaczały rozwój rolnictwa po okresie uwłaszczenia. Obecnie najwięcej wielkoobszarowych gospodarstw rolnych powyżej 100 ha jest zlokalizowanych na terenie województw: dolnośląskiego, warmińsko-mazurskiego, wielkopolskiego i zachodniopomorskiego. Są to również województwa o wysokiej kulturze rolnej, dużym zużyciu nawozów mineralnych i wysokim plonowaniu zbóż.

Zupełnie inaczej sytuacja wygląda na Podkarpaciu i w Małopolsce, gdzie zużywa się dwukrotnie mniej nawozów, a plonowanie jest istotnie mniejsze. Zdumiewa wręcz liczba ciągników w Polsce wynosząca 1436136 sztuk, co plasuje nasz kraj na 5. miejscu w świecie. Zróżnicowanie jest również w tym przypadku bardzo duże. W województwie małopolskim jest ich ponad 81 tys., podczas gdy w zachodniopomorskim, gdzie gospodarstw ponad 100 ha jest 1566, rolnicy mają do dyspozycji 28,5 tys. ciągników [GUS 2016, s. 134]. Zróżnicowanie regionalne zaznacza się także w innych obszarach, takich jak wykształcenie, wydajność pracy, dochodowość czy wyposażenie w maszyny i urządzenia rolnicze.

Na polską wieś i do rolnictwa trafia 1/3 transferów z budżetu UE. Nastąpiła znaczna poprawa sytuacji dochodowej mieszkańców wsi. Jednocześnie wciąż utrzymują się niekorzystne dla mieszkańców wsi różnice w relacji miasto - wieś. W stosunku do przeciętnej

Boston Consulting Group podzieliło produkcyjne firmy chemiczne ze względu na uwarunkowania rynkowe na trzy grupy: graczy niskokosztowych, regionalnych liderów oraz graczy ogólnoświatowych. Każdy z nich przyjmuje inną strategię budowania kanałów dystrybucji w dotarciu do klienta finalnego.

2 „Cicha dzierżawa” polega na wydzierżawieniu użytków rolnych innemu przedsiębiorcy rolnemu bez zgłaszania tego faktu stosownemu urzędowi. 
krajowej dochód rozporządzalny na osobę na wsi utrzymuje się od lat na poziomie około 80\% [Nurzyńska, Poczta (red.) 2014, s. 4-7]. Trzeba jednak zaznaczyć, że na wsi mieszka wiele osób, które nie utrzymują się z pracy w gospodarstwach rolniczych.

Polskie rolnictwo charakteryzuje specyfika w porównaniu do innych krajów europejskich, która wyraża się głównie dużym odsetkiem niewielkich gospodarstw osób fizycznych, o stosunkowo małym kontakcie z rynkiem. Zmiana ustroju społeczno-gospodarczego na przełomie lat osiemdziesiątych i dziewięćdziesiątych ubiegłego wieku rozpoczęła proces zmian. Część gospodarstw rolnych zaczęła dynamicznie się rozwijać, traktując rolnictwo jak biznes, część zaś tzw. tradycyjnych gospodarstw zorientowana była raczej na przetrwanie. W tej drugiej grupie znajdowały się również gospodarstwa, które potrafiły wykorzystać poprawę warunków gospodarowania, uzyskując zdolność konkurencyjną, dzięki czemu zaczęły osiągać dochody. Grupy te można podzielić za Andrzejem Kowalskim, który ze względu na pogłębiający się proces społecznego, ekonomicznego i technologicznego zróżnicowania rolnictwa wyodrębnia rolnictwo komercyjne, wielofunkcyjne i socjalne [Kowalski 2014, s. 73].

Łączna liczba gospodarstw ze zdolnością konkurencyjną i tych, które mają potencjał do osiągnięcia tej zdolności, wyniosła w latach 2010-2012 około 209 tys. (tab. 2.). Nastąpił wzrost ich liczby o około 20\% w stosunku do sytuacji z lat 2005-2007. Biorąc pod uwagę wspomnianą dynamikę można przypuszczać, że obecnie liczba tego rodzaju gospodarstw jest jeszcze większa. Szacuje się, że gospodarstwa ze zdolnością konkurencyjną i z możliwościami jej uzyskania wykorzystywały do produkcji w 2010 roku około 52,5\% powierzchni użytków rolnych będących w posiadaniu gospodarstw rolnych osób fizycznych, ale ich udział w krajowej towarowej produkcji rolniczej był z całą pewnością większy [Jóźwiak (red.) 2014, s. 22]. W grupie gospodarstw osób prawnych jest zdecydowanie większy udział gospodarstw ze zdolnością konkurencyjną i takich, które wkrótce mogą ją zyskać (93-94\%), a zatem niewielki odsetek tych gospodarstw można uznać za gospodarstwa bez zdolności konkurencyjnej. Reasumując ten wątek należy stwierdzić, że w Polsce na ponad 1,4 mln gospodarstw rolnych tylko ponad 200 tys. to gospodarstwa towarowe, a pozostałe to gospodarstwa socjalne. To bardzo ważny wniosek dla każdego, kto interesuje się polskim rynkiem rolnym.

W czerwcu 2014 r. Agencja „Społeczeństwo, Media, Gospodarka, Polityka” przeprowadziła badania liderów opinii w środowisku wiejskim [Raport SMGP 2014] ${ }^{3}$. Z przepro-

Tabela 2. Liczba gospodarstw osób fizycznych ze zdolnością konkurencyjną i tych z przesłankami jej osiągnięcia

\begin{tabular}{|c|c|c|c|c|}
\hline \multirow[t]{3}{*}{ Grupy gospodarstw } & \multicolumn{4}{|c|}{ Wielkości w latach } \\
\hline & \multicolumn{2}{|c|}{$2005-2007$} & \multicolumn{2}{|c|}{$2010-2012$} \\
\hline & $\begin{array}{l}\text { liczba } \\
\text { [tys.] }\end{array}$ & $\begin{array}{c}\text { udział } \\
{[\%]}\end{array}$ & $\begin{array}{l}\text { liczba } \\
\text { [tys.] }\end{array}$ & $\begin{array}{c}\text { udział } \\
{[\%]}\end{array}$ \\
\hline Gospodarstwa ze zdolnością konkurencyjną & 90,7 & 5,2 & 90,3 & 7,1 \\
\hline $\begin{array}{l}\text { Gospodarstwa z możliwościami uzyskania } \\
\text { zdolności konkurencyjnej }\end{array}$ & 83,8 & 4,8 & 119,1 & 8,0 \\
\hline Gospodarstwa bez zdolności konkurencyjnej & 1567,1 & 90,0 & 1270,8 & 84,9 \\
\hline
\end{tabular}

Źródło: [Jóźwiak (red.) 2014, s. 22].

\footnotetext{
Badanie zrealizowano na losowej próbie 500 respondentów, którymi byli sołtysi. Z racji regularnych kontaktów z lokalną społecznością zostali oni potraktowani jako lokalni liderzy opinii. Na potrzeby badania wylosowano województwa, a następnie w ich ramach powiaty, w których przeprowadzono w dniach 10-20 czerwca $2014 \mathrm{r}$. wywiady telefoniczne wspomagane komputerowo (CATI).
} 
wadzonych badań wynika, że po akcesji do UE wzrósł prestiż zawodu rolnika w ocenie Polaków (59\% ankietowanych wskazało na korzystny kierunek zmian), a jednocześnie oni sami uważali, że zawód ten nie jest zbytnio szanowany w Polsce (63\% wskazań). Z wypowiedzi respondentów wyłaniał się czarno-biały obraz polskiej wsi. Wyraźnie zarysowany został podział na dwie diametralnie różniące się grupy posiadaczy gospodarstw. Pierwsza grupa to „typ nowoczesny” rolnik, który poszukuje innowacyjnych rozwiązań, docenia wagę inwestycji, sprawnie radzi sobie z biurokratycznymi formalnościami i priorytetem jest dla niego dochodowość gospodarstwa. Druga grupa to „typ tradycyjny” właściciel mniejszego gospodarstwa, który jest przywiązany do przyzwyczajeń i metod stosowanych od wielu lat, przekazywanych z pokolenia na pokolenie. Nie jest on gotowy na wprowadzanie zmian, nawet jeśli mogłyby przynieść podniesienie standardu życia. Wykazuje się on nieufnością w stosunku do nowości oraz brakuje mu orientacji na przyszły rozwój. Ponadto pojawia się też typ trzeci - „młody, aspirujący rolnik”, który rozumie, że aby się rozwijać musi poszerzać nie tylko areał, ale i umiejętności. Wciąż się kształci, ale łatwiej zdobywa wiedzę agrotechniczną niż biznesową.

Niezwykle istotne zmiany zaszły w sposobie komunikowania się na polskiej wsi z wykorzystaniem narzędzi IT. Dostęp do Internetu w gospodarstwie domowym, jak wynika z badań Ibris przeprowadzonych w 2015 r., miało ponad 3/4 (77,2\%) badanych przedsiębiorców rolnych ${ }^{4}$. Jednak korzystanie $\mathrm{z}$ wiedzy dostępnej w Internecie dotyczącej prowadzenia przedsiębiorstwa rolnego lub podejmowania decyzji ekonomicznych deklarowało tylko 36,7\% ankietowanych [Ibris raport, 2015, s. 13-14]. Dla porównania w 2006 r. korzystanie z Internetu deklarowało tylko 10\% respondentów, tak więc postęp w tym zakresie jest ogromny. Jednak zróżnicowanie regionalne daje i w tej kwestii znać o sobie. W badaniach gospodarstw rolnych powyżej 50 ha przeprowadzonych przez ABM w 2012 r. wykazano, że odsetek gospodarstw dysponujących dostępem do Internetu był najwyższy na Kujawach i Pomorzu (93\%), najniższy zaś w województwach świętokrzyskim, małopolskim i podkarpackim (67\%) [ABM 2012, s. 248]. Pojawił się zatem nowy kanał komunikacji producentów i dystrybutorów ze swoimi klientami, z którego szybko uczestnicy rynku rolnego zrobili użytek.

\section{NOWE ŹRÓDŁA BUDOWANIA PRZEWAGI KONKURENCYJNEJ}

Dystrybutorzy środków do produkcji rolnej dostrzegli potencjał w budowaniu wartości swoich firm przez odpowiednie zarządzanie relacjami z klientem. Stosowali, świadomie czy nie, to, co dzisiaj nauka nazywa marketingiem relacji, polegającym na budowaniu długotrwałych, korzystnych relacji przedsiębiorstwa ze klientami [Krzepicka 2010, s. 441-450]. Wszyscy czołowi dystrybutorzy doceniają wartość kapitału relacyjnego, czasem zwanego kapitałem rynkowym czy klienckim [Edvinsson 2001, s.35]. Tutaj klient-rolnik bardziej jest partnerem aniżeli ,zdobyczą” dla dystrybutora. Nieuczciwa jedna transakcja może doprowadzić do utraty wartościowego klienta. Dystrybutorzy koncentrują się na poszukiwaniu najlepszych sposobów rozwiązywania problemów klientów [Amstrong, Kotler 2012, s. 56]. W coraz bogatszej literaturze przedmiotu pojawiły się nowe pojęcia opisujące relacje z klientami, takie jak: ,kapitał

\footnotetext{
Badania przeprowadzono na próbie ogólnopolskiej, dobranej losowo-kwotowo przez Instytut Badań Rynkowych i Społecznych „Ibris” w okresie od 24 lipca do 12 sierpnia 2015 r. Zrealizowano je metodą bezpośrednich standaryzowanych wywiadów kwestionariuszowych (PAPI).
} 
klientów”, „wartość życiowa klienta”, „rentowność klientów”, „stopa retencji klientów” czy „cykl życia klienta” [Dobiegała-Korona, Doligalski 2010, Doligalski 2013].

Ze względu na sposób obsługi przedsiębiorców rolnych dystrybucję w Polsce można podzielić na kilka obszarów:

- dystrybucja towarów producentów krajowych i zagranicznych, zarówno do produkcji zwierzęcej, jak i roślinnej;

- logistyka - firmy często są w posiadaniu kilku baz logistycznych, zapewniających sprawne dostawy środków produkcji, a także transport płodów rolnych na terenie całego kraju;

- usługi finansowe - kredyty, leasing, spłaty ratami oraz ubezpieczenia dla gospodarstw rolnych, a także pomoc w uzyskaniu zwrotów kosztów inwestycji z funduszy pomocowych UE;

- doradztwo rolne dostosowane do zmieniającego się rynku rolnego przez sieć tzw. konsultantów rolnych; organizowanie dla swoich klientów seminariów i szkoleń z nowych technik agrarnych; wydawanie fachowych pism o innowacyjnych metodach produkcji rolnej, itp.;

- współpraca ze społecznością lokalną - w szczególności polega na rozwiązywaniu problemów wsi związanych z dostępem do edukacji, opieki zdrowotnej, dóbr kultury oraz na wspieraniu instytucji lokalnych.

Na szczególną uwagę w kształtowaniu nowego modelu biznesowego w dystrybucji zasługują usługi finansowe oraz doradztwo rolnicze.

Oferta finansowania sektora rolno-spożywczego jest dostępna w kilku bankach w Polsce, w tym głównie w bankach spółdzielczych, a w innych jest intensywnie rozwijana (np. PKO BP czy Alior Bank). Banki dostrzegły potencjał dynamicznie rozwijającego się sektora rolno-spożywczego. O ile finansowanie przedsiębiorstw jest doskonale rozpoznane, o tyle wiele problemów nadal stwarza kredytowanie przedsiębiorców rolnych. Podstawowe trudności w finansowaniu sektora rolno-spożywczego wynikają ze specyfiki działalności rolnej, która różni się od innych z uwagi na:

- długi cykl produkcyjny, sezonowość produkcji, a tym samym przepływów pieniężnych,

- małą zdolność zmiany kierunków produkcji i wprowadzania modyfikacji w trwającym cyklu produkcyjnym,

- $\quad$ wysoką kapitałochłonność w odniesieniu do poziomu przychodów ze sprzedaży oraz do generowanej nadwyżki finansowej,

- wysokie koszty stałe działalności,

- niską elastyczność posiadanych aktywów w kontekście wymaganych przez banki zabezpieczeń spłaty kredytu.

Jedną z najważniejszych trudności w finansowaniu rolnictwa jest bardzo ograniczony dostęp do rzetelnych danych o wielkości prowadzonej produkcji. Rolnik jest zobowiązany przedstawić wymagane przez bank dokumenty niezbędne do oceny jego sytuacji ekonomiczno-finansowej oraz sposobu wykorzystania kredytu. Tymczasem w przypadku indywidualnych gospodarstw rolnych zakres prowadzonej ewidencji księgowej jest znacząco ograniczony. Zdecydowana większość polskich rolników to rolnicy tzw. ryczałtowi, którzy nie mają obowiązku prowadzenia żadnej ewidencji księgowej lub podatkowej. Jedynie rolnicy indywidualni prowadzący działalność rolniczą o dużych rozmiarach mają obowiązek prowadzenia ksiąg rachunkowych. Ze względu na ograniczone obowiązki prowadzenia ewidencji lub sprawozdawczości przez rolników indywidualnych dostęp do rzetelnych informacji o ich sytuacji ekonomiczno-finansowej stanowi istotną barierę w ocenie wiarygodności kredytowej ${ }^{5}$.

Ocena wynikająca z analizy wewnętrznej PKO BP w 2015 r. 
Pomimo tego, że przedsiębiorcy rolni mają jedno z najatrakcyjniejszych zabezpieczeń, jakim jest grunt rolny, którego wartość wzrasta systematycznie od wielu lat, to jednak ustanowienie na nim zabezpieczenia wiąże się z wieloma problemami. Przede wszystkim bardzo często grunty rolne są już obciążone innymi posiadanymi przez klienta kredytami i kolejny bank może jedynie wpisać się na dalsze miejsce na liście wierzycieli. Ponadto grunty rolne miewają obciążenia w formie różnego rodzaju służebności gruntowych lub osobistych, które dodatkowo komplikują kwestie wyceny i zbywalności gruntu. Czasem też, z obawy o utratę ojcowizny, gospodarz bardzo niechętnie udziela gruntu na zabezpieczenie.

Problemem jest także brak podstawowej wiedzy z zakresu ekonomii, w tym finansów, dotyczących własnego biznesu i brak umiejętności rozgraniczenia pomiędzy finansowaniem życia prywatnego a finansowaniem działalności gospodarczej.

W polskim rolnictwie ukształtowały się dwa dominujące sposoby kredytowania:

- $\quad$ kredyt kupiecki - realizowany u dostawcy środków do produkcji jako sprzedaż z odroczonym terminem płatności, wykorzystywany głównie do zakupu środków ochrony roślin, nawozów czy materiału siewnego,

- $\quad$ kredyty bankowe, pożyczki czy leasing zaciągane w instytucjach kredytowych: bankach lub firmach leasingowych, a wykorzystywane do zakupu sprzętu rolniczego czy ziemi. Z obserwacji wiodących dostawców środków do produkcji rolnej wynika, że kredyt kupiecki jest obecnie najatrakcyjniejszą formą kredytowania środków do produkcji rolnej. Dystrybutorzy potrafili odbiurokratyzować proces udzielania odroczonego terminu płatności bez rezygnacji z oceny wiarygodności kredytowej klienta czy zabezpieczenia zwrotu kredytu. Wypracowali także własne zasady udzielania kredytu kupieckiego. Obecnie to już integralna część oferty w strategii handlowej budowania relacji z klientami rolnymi [Grupa Azoty Puławy 2015-2016].

W ostatnich latach pojawiła się nowa oferta finansowania działalności produkcyjnej w rolnictwie. Rozwiązanie to polega na udzielaniu przedsiębiorcom rolnym finansowania obrotowego lub inwestycyjnego na warunkach preferencyjnych, określonych w umowie ramowej, zawartej pomiędzy bankiem a dużym podmiotem z sektora rolno-spożywczego, którym najczęściej jest dystrybutor. Podmiot ten, w tej koncepcji zwany „liderem powiązań”, współpracuje bezpośrednio z korzystającymi z finansowania producentami rolnymi. Zaletą tego rozwiązania dla lidera powiązań jest budowanie dobrych relacji ze współpracującymi podmiotami rolnymi oraz zwiększanie przejrzystości rozliczeń dzięki wsparciu oferowanemu przez bank, natomiast dla przedsiębiorców rolnych oznacza niższe koszty finansowania. Co więcej, lider powiązań może w ramach współpracy z bankiem zaproponować klientowi upust na oferowane produkty, a nawet partycypować w kosztach finansowania. Bank w ramach współpracy z liderem powiązań może prowadzić wspólne działania marketingowe i łatwiej dotrzeć $\mathrm{z}$ ofertą do potencjalnych klientów. Lider powiązań ma dużą wiedzę o swoich odbiorcach, która nie jest dostępna bankom ${ }^{6}$. Warto zauważyć, że dystrybutorzy środków do produkcji rolnej, przejmując funkcję finansowania działalności gospodarczej swoich klientów-rolników, uszczelniają rolniczy łańcuch wartości oraz zapewniają sobie dodatkowe źródło dochodów. Podobną rolę pełnią usługi doradztwa rolniczego. Stały się one obecnie jednym z ważniejszych źródeł budowania przewagi konkurencyjnej.

W Polsce organizacja systemu doradztwa rolniczego oparta jest na regulacjach ustawy z dnia 22 października 2004 r. o jednostkach doradztwa rolniczego [Dz.U. 2004.251.2507

$6 \quad$ Prezentowany model współpracy rozwija np. PKO Bank Polski. 
oraz Dz.U. 2016.1176) ${ }^{7}$. Kolejne nowelizacje ustawy usankcjonowały tworzenie doradztwa w systemie FAS (Farm Advisory System), składającego się z podmiotów publicznych i prywatnych. Trzeba jednak przyznać, że doradztwo publiczne jak dotąd odgrywa rolę dominującą. Dotacja z budżetu państwa dla ośrodków doradztwa rolniczego (ODR) w ostatnich latach ustabilizowała się na poziomie około $1181 \mathrm{mln}$ zł, z czego prawie $80 \%$ przeznacza się na wynagrodzenia i pochodne. Należy dodać, że w ODR zatrudnionych jest ponad 4,2 tys. pracowników, w tym 3,5 tys. kadry kierowniczej i doradczej [http:// www.minrol.gov.pl/Ministerstwo/Biuro-Prasowe/Informacje-Prasowe/Osrodki-Doradztwa-Rolniczego-nowy-status]. W rozwiniętych gospodarczo krajach następuje stopniowy proces komercjalizacji usług doradczych m.in. ze względu na rosnące wymagania rolników, konkurencyjność na rynku usług doradczych i relatywnie małą efektywność państwowych systemów doradztwa [Dorofiejczuk-Paradny, Zawisza 2011, s. 17-20].

Dla prywatnych firm dystrybucyjnych transfer wiedzy i działania informacyjne, prowadzone zarówno przez tradycyjne formy szkoleniowo-doradcze, jak i nowsze, takie jak: warsztaty, coaching czy demonstracje, są bardzo ważne. Te ostatnie stały się standardem w trakcie organizowanych „Dni Pola”. Doradztwo to prowadzone jest przez własną kadrę agrotechników i zapraszanych nauczycieli akademickich z polskich uczelni. Ten rodzaj doradztwa wpisuje się w model biznesowy firm dystrybucyjnych. Niektóre z nich w tym celu założyły osobne firmy świadczące usługi doradcze ${ }^{8}$. Należy podkreślić, że poziom tej usługi jest coraz wyższy, kompetentny, uwzględniający najnowsze zdobycze nauki i praktyki nie tylko krajowej [Pokojski 2014] . Doradztwo oferowane przez dystrybutorów czy też producentów środków do produkcji rolnej jest elementem modelu biznesowego producenta/dystrybutora służącego wsparciu obsługi swoich klientów. Usługa ta jest wspierana nowoczesnymi narzędziami IT, zarówno w komunikacji, jak i technikach agrarnych, jak np. rolnictwo precyzyjne. W badaniach IERiGŻ-PIB wskazano, że systematycznie wzrasta odsetek producentów i dystrybutorów służących doradztwem (poza systemem ODR) [np. Dudek 2013, s. 25]. Reasumując ten wątek, należy zauważyć, że w usługach doradztwa rolniczego, niezależnie od podmiotu je oferującego, nazbyt dużo miejsca zajmuje doradztwo związane z wdrażaniem unijnych programów wsparcia, co jest konsekwencją ciągłych zmian wspólnej polityki rolnej UE. Zjawisko to jest tak intensywne, że zaczęto je określać mianem „doradztwa papierowego" (ang. paper advisory) związanego w coraz większym stopniu z usługą przygotowywania wniosków o wsparcie ze środków unijnych [Drygas 2012].

Organizacja finansowania oraz świadczone usługi doradztwa rolniczego dają dużą przewagę konkurencyjną oferującym je dostawcom środków do produkcji rolnej. Obecnie dystrybutor ma wiedzę m.in. na temat potencjału zakupowego $\mathrm{w}$ regionie swojego działania, struktury i częstotliwości zakupów, hierarchii zakupów każdego ze swoich większych klientów, ich oczekiwań i preferencji. Wiedza ta pozwala mu odpowiednio zarządzać portfelem klientów, podnosić wartość kapitału relacyjnego, tym samym wartość tego rolniczego ogniwa łańcucha wartości.

\footnotetext{
Zmianie uległ status prawny ODR - z samorządowych wojewódzkich osób prawnych stały się państwowymi jednostkami organizacyjnymi posiadającymi osobowość prawną.

$8 \quad$ Np. firma Osadkowski powołała do życia firmę doradczą Agrainvest.

9 Grupa Azoty Puławy wspólnie ze Szkołą Główną Gospodarstwa Wiejskiego organizuje studia podyplomowe dla swoich przedstawicieli regionalnych i pracowników dystrybutorów współpracujących z rolnikami. Profil studiów "Obrót nawozami i środkami ochrony roślin w systemie zrównoważonego rolnictwa" przygotowany został wspólnie z producentem. Absolwenci otrzymują oprócz dyplomu dwa certyfikaty upoważniające do obrotu, konfekcjonowania i stosowania środków ochrony roślin przeznaczonych dla profesjonalnych użytkowników.
} 


\section{PODSUMOWANIE}

1. Model biznesowy dystrybucji w Polsce wciąż ewoluuje, dostosowując się do dynamiki zmian oczekiwań swoich klientów. W poszczególnych ogniwach rolniczego łańcucha wartości poszukuje się nowych możliwości tworzenia i przechwytywania najwyższych marż w łańcuchu firm, które uczestniczą w wytworzeniu i dostarczeniu produktu klientowi finalnemu. Najsilniejsi próbują integracji pionowej i poziomej, jak również różnych formuł partnerstwa w celu skrócenia kanału dystrybucji i przejęcia jak największej wartości dodanej w całym łańcuchu.

2. Nową rolę dystrybucji na rynku rolnym jako ogniwa rolniczego łańcucha wartości wyznaczyły, z jednej strony, poszukiwania producentów (np. nawozów, środków ochrony roślin czy maszyn i urządzeń rolniczych) nowej formuły dystrybucji swoich produktów, a z drugiej strony, potrzeby przedsiębiorców rolnych, którzy oczekiwali bardziej kompletnych, profesjonalnych form współpracy z dostawcami.

3. Dystrybutorzy w poszukiwaniu nowych źródeł przewagi konkurencyjnej wciąż wzbogacają ofertę zorientowaną na przedsiębiorcę rolnego. Na szczególną uwagę w kształtowaniu się nowego modelu biznesowego w dystrybucji zasługują usługi finansowe oraz doradztwo rolnicze. Zwraca również uwagę fakt, że coraz chętniej sięgają po narzędzia zarządzania wartością klienta.

\section{LITERATURA}

ABM, 2012: Opis sytuacji ZAP na rynku polskim, raport z badań, Puławy-Warszawa.

Agrium, 2010: Growing Across the Value Chain. http://www.agrium.com/en/what-we-do/history (18 kwietnia 2017).

Amstrong Gary, Philip Kotler, 2012: Marketing, Wolters Kluwer, Warszawa.

Berger Roland, 2015: Supply chain management \& Logistics, Functional know-how, Expertise, Roland Berger.

Brodnicki Zbigniew, Eugeniusz Karol Chyłek, 1999: Doradztwo w agrobiznesie, Wyd. ART, Olsztyn, 21.

Cioch Grzegorz, Daria Kłosowska, 2009: Rynek nawozowy - dystrybucja rządzi, „Miesięcznik Gospodarczy. Nowy Przemysł", 90(137), Katowice.

Dawson John, 2014: Commercial Distribution in Europe, Routledge Revivals.

Dobiegała-Korona Barbara, Tymoteusz Doligalski (red.), 2010: Zarządzanie wartościa klienta. Pomiar i strategie, Poltext, Warszawa.

Doligalski Tymoteusz 2013: Zarzązanie wartościa klienta. Próba charakterystyki, „Marketing i Rynek", 6/2013.

Dorofiejczuk-Paradny Justyna, Zawisza Sławomir 2011: Ewolucja systemów wsparcia doradczego na świecie - od doradztwa państwowego do prywatnych usług doradczych, Zagadnienia doradztwa rolniczego nr 1/11(63), Centrum Doradztwa Rolniczego w Brwinowie, Oddział w Poznaniu.

Drygas Mirosław 2012: Postulowany system doradztwa rolniczego w Polsce po $2013 \mathrm{r}$. w świetle wymogów Komisji Europejskiej, Biuro Analiz Sejmowych, Warszawa. http://www.senat.gov.pl/ download/gfx/senat/pl/defaultaktualnosci/2/1564/1/4.pdf, dostęp 10 sierpnia 2017.

Dudek Michał 2013: Określenie roli kapitalu ludzkiego w rozwoju obszarów wiejskich, Instytut Ekonomiki Rolnictwa i Gospodarki Żywnościowej, Warszawa.

Edvinsson Leif, Malone Michael, 2001: Kapitat intelektualny, Wydawnictwo Naukowe PWN, Warszawa.

Grochowska Renata, 2014: Globalne tańcuchy wartości wyzwaniem dla sektora rolnego w Polsce, Kierunki rozwoju rolnictwa i polityk rolnych - wyzwania przyszłości, IERiGŻ-PIB, Warszawa, zeszyt nr 127.

Grupa Azoty Puławy, materiały wewnętrzne z lat 2015-2016.

GUS 2016: Rocznik statystyczny rolnictwa 2016, Warszawa. 
Ibris, 2015: Przedsiębiorcy rolni o obecnej sytuacji w rolnictwie, raport z badań 2015, Warszawa.

Jóźwiak Wojciech (red.) 2014: Efektywność, Koszty produkcji i konkurencyjność polskich gospodarstw rolnych obecnie $i$ w perspektywie średnio- oraz dhugoterminowej, IERiGŻ-PIB, Warszawa.

Kowalski Andrzej, 2014: Wyzwania dla sektora rolno-spożywczego we współczesnym świecie, [w] Raport „25 lat polskiego rolnictwa Bezpieczeństwo żywnościowe w Europie”, Igras Janusz (red.), C.K. Puławy.

Koźmiński Andrzej, 2004: Zarzadzanie w warunkach niepewności, Wydawnictwo Naukowe PWN, Warszawa.

Krzepicka Alicja, 2010: Wartość dodana w marketingu relacji [w] Zarzadzanie wartościa klienta. Pomiar i strategie, red. Barbara Dobiegała-Korona, Tymoteusz Doligalski, Wydawnictwo Poltext, Warszawa.

Lista 500 największych firm Rzeczpospolitej. http://www.rp/pl, dostęp: 18 grudnia 2016.

Michalski Eugeniusz, 2003: Marketing, Wydawnictwo Naukowe PWN, Warszawa.

Nurzyńska Iwona, Poczta Walenty (red.), 2014: Raport o stanie wsi. Polska wieś 2014 - Synteza, Wydawnictwo Naukowe Scholar, Warszawa.

Pokojski Zenon, 2014: Doradztwo rolnicze we wdrażaniu innowacji w polskim sektorze żywnościowym, Biuro Analiz Sejmowych, Warszawa. http://www.senat.gov.pl/gfx/senat/userfiles/_public/ k8/.../2014/.../1096-14a_pokojski.pdf, dostęp 11 lutego 2017.

Porter Michael Eugene, 2001: The value chain and competitive advantage. Understanding business: Processes, Routledge London.

SMGP, 2014: Badanie liderów opinii w środowisku wiejskim, raport z badań, Warszawa.

The creation of Ferti Supply, 2006: https://www.kfst.dk/, dostęp: 18 kwietnia 2017.

Ustawa z dnia 22 czerwca 2016 r. o zmianie ustawy o jednostkach doradztwa rolniczego, Dz.U. poz. 1176.

Ustawa z dnia 22 października 2004 r. o jednostkach doradztwa rolniczego, Dz.U. 2004, nr 251, poz. 2507 , z późn. zm.

Yara Impact Review, 2011: Oslo, materiał informacyjny firmy.

http://www.minrol.gov.pl/Ministerstwo/Biuro-Prasowe/Informacje-Prasowe/Osrodki-Doradztwa-Rolniczego-nowy-status, dostęp 2 sierpnia 2017.

https://www.agrofert.cz/en/about-agrofert, dostęp 18 kwietnia 2017.

\title{
Zenon Pokojski \\ DISTRIBUTION OF PRODUCTS FOR AGRICULTURE IN POLAND - IN SEARCH OF NEW SOURCES OF COMPETITIVE ADVANTAGE
}

\begin{abstract}
Summary
The distribution of agricultural products in Poland is considered to be relatively weak compared to other European countries. There is a huge number of small players whose strategies are based primarily on price competition. This situation, however, after Poland's accession to the European Union began to change rapidly. The number of players began to decrease, distributors have overtaken the roles of wholesalers and retailers. The distribution model in Poland is still evolving, adjusting the offer to dynamic changes to meet the expectations of customers. Individual elements of the agricultural value chain seek new opportunities to create and capture the highest margins in the portfolio of companies that participate in the production and delivery of a product to a farmer. The goal of this study is to present changes in distribution as a link in the agricultural value chain. The author will more broadly present new phenomena in this market, such as agricultural advisory services and the organization of financing the economic activity of farmers. The publication is the result of a research study based on data from TNS Polska and Ibris conducted in 2015 and observations as Vice President of GA Pulawy responsible for this area.
\end{abstract}

Adres do korespondencji: Dr Zenon Pokojski Uniwersytet Marii Curie Skłodowskiej w Lublinie, Laboratorium Praktyki Biznesu pl. Marii Skłodowskiej-Curie 5, 20-031 Lublin e-mail: zenon.pokojski@umcs.pl 